\title{
THE EFFECT OF PHYSICAL FITNESS GYMNASTICS TRAINING 2012 ON INCREASING OF PHYSICAL FITNESS
}

\author{
Hasanuddin Jumareng1, Asmuddin², Aliasis Maruka ${ }^{3}$, Abdul Saman ${ }^{4}$, \\ Badaruddin $^{5}$, Edi Setiawan ${ }^{6}$, Abdurrohman Muzakki ${ }^{7}$ \\ Universitas Halu Oleo, Kendari ${ }^{1,2,3,4,5}$, Universitas Suryakancana, Cianjur ${ }^{6}$, \\ Universitas Muhammadiyah Malang ${ }^{7}$ \\ hasanuddinjumareng@uho.ac.id, asmuddin@uho.ac.id, Aliasismaruka@uho.ac.id, \\ abdulsaman@uho.ac.id, Badaruddin@uho.ac.id, edisetiawanmpd@gmail.com, \\ Abdurrohmanmuzakki@gmail.com
}

\begin{abstract}
This research is motivated by the declining level of physical fitness possessed by students at SMA Negeri 8 Kendari. This study aims to determine the effect of 2012 physical fitness exercise on increasing students' physical fitness. In this study using the experimental method. Experimental research is research that aims to determine the cause and effect that occurs in research subjects after being given an action or treatment. In this research using a quasi-experimental method, the design of this research is One Group PretestPosttest Design. This research was conducted for 9 weeks with a frequency of exercise 3 times a week, namely on Thursday, Friday and Saturday. The population in this study were all seventh grade students of SMA Negeri 8 Kendari, totaling 98 students and a sample of 10 students taken by random sampling technique, which is a sampling technique that provides equal opportunities for students to become samples in this study. Statistical analysis using IBM SPSS version 25 to look for descriptive data (mean, standard deviation), normality test (shapiro-wilk) and homogeneity (levene test) and in this study using t-test and paired sample t-test for hypothesis testing in research and for the significance level using 0.05. The findings of this study indicate that the post-test value by calculating $t$-count $=6.474>t$-table $=1.833$ and $0.006<0.05$. This means that there is an effect of the consequences of 2012 physical fitness exercise on increasing the physical fitness of the students. Thus, in this study, it was confirmed that the 2012 physical fitness training was positively proven to increase the physical fitness of students from low to high. This research has implications for providing information for lecturers, teachers or instructors regarding the importance of using a 2012 physical fitness training for students who have a relatively low level of physical fitness.
\end{abstract}

Keywords: Training, Gymnastics, Physical fitness

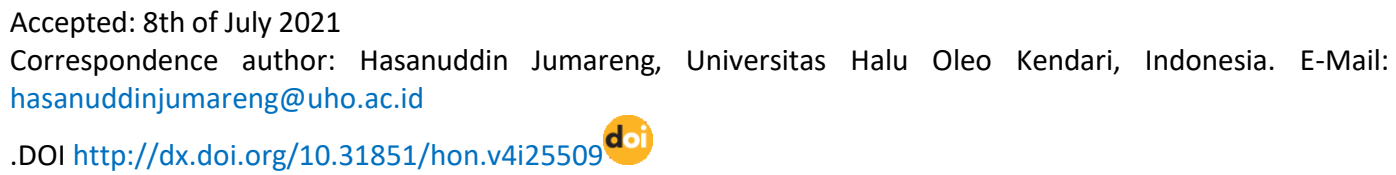


Hasanuddin Jumareng, Asmuddin, Aliasis Maruka, Abdul Saman, Badaruddin, Edi Setiawan, Abdurrohman Muzakki (2021)

The Effect Of Physical Fitness Gymnastics Training 2012 On Increasing Of Physical Fitness

\section{HALAMAN Jendral A. Yani Street Lorong Gotong Royong 9/10 Ulu OLAHRAGA - NUSANTARA email jurnal: jurnalhon@univpgri-palembang.ac.id JURALJHUKCLMRAGHA situs web: http://www.univpgri-palembang.ac.id}

Accredited SINTA 3

\section{INTRODUCTION}

Education as a process of human being founding that a long life directly, physical education, sports and health that taught in schools has a very important role (Wanto, 2018), which is to provide opportunities for students to be directly involved in various learning experiences through physical activities. According to Soraya, Sugihartono, \& Defliyanto, (2019) sport is a human culture, its mean that it cannot be called a sports activity if there are no human being factors that play a role physically in carrying out the sports activity. One of the reasons students done physical activity or sports is that students getting physical fitness from the sports activity (Susanto \& Nuraini, 2019)., itself which effects their body health so that the students can done other activities as well as possible (Chen, HammondBennett, Hypnar, \& Mason, 2018; Pasaribu \& Mashuri, 2019). Physical fitness in school environment needs to be founding to support the achievement of teaching and learning process optimally besides that students can complete assignments well without experience significant fatigue (Anggitasari, Dieny, \& Candra, 2019; Edi Setiawan, Budiarto, \& Afriyuandi, 2020), because if students have a good physical fitness it will be able to carry out their learning obligations well either. However, if the students have a bad level of physical fitness, it is possible that students will not be able to accept the learning responsibility which is actually the assignment from the students (Xu, Yao, Kang, \& Duan, 2020). And finally, the higher the students 'physical fitness level, that the higher students' enthusiasm for learning either (Abdurrahim \& Hariadi, 2018). Physical fitness and health are needed by students to enhance their learning abilities and complete other assignment, so that educational goals will be achieved. In addition, according to a recent study reported that physical fitness is also useful for living life and if someone has low physical fitness, then that person will easily get tired in carrying out daily activities (Bayu et al., 2021). Some studies have reported the decreasing physical fitness after 8 to 12 weeks of inactivity (Setiawan, Iwandana, Festiawan, \& Bapista, 2020; Patah, Jumareng, Setiawan, Aryani, \& Gani, 2021). One of the 
Hasanuddin Jumareng, Asmuddin, Aliasis Maruka, Abdul Saman, Badaruddin, Edi Setiawan, Abdurrohman Muzakki (2021)

The Effect Of Physical Fitness Gymnastics Training 2012 On Increasing Of Physical Fitness

\section{HALAMAN Jendral A. Yani Street Lorong Gotong Royong 9/10 Ulu OLAHRAGA Palembang South Sumatera

efforts that can be made so that children's physical fitness continues to improve by providing 2012 physical fitness exercises.

The 2012 physical fitness exercise is one of the exercises by performing several energetic movements accompanied by music. The characteristics and structure of the gymnastics movement is a physical activity that is very suitable for developing the motor quality and physical quality of the children at the same time (Sukamti, Zein, \& Budiarti, 2016). Gymnastics contains locomotor movements which are considered capable to inceasing of strength, speed, power, endurance, agility, and balance aspects to the children (Sukamanti, Budiarti, \& Nurfadhila, 2020). Associated with non-locomotor training, it can increase of strength, flexibility, and static balance aspects. Associated with the manipulative movement of gymnastics is able to stimulate of coordination and processing ability to stimuli the child's consciousness center. The physical fitness gymnastics 2012 is able to optimize various domains that exist in education, in physical fitness gymnastics 2012 the form of stories has the ability to train those areas. Gymnastics 2012 is a series of gymnastic movements that aim to incease or maintain physical fitness. In accordaing with the principles and characteristics of physical fitness gymnastics, the movements are planned, arranged systematically, and aim to obtain physical health and fitness (Aminah, Shadiqin, \& Kahri, 2020). In performing of physical fitness gymnastics 2012, it is always accompanied by existing music. Physical fitness training 2012 consists of three main movements by using musical rhythms, namely warming-up movements, core movements and cooling down movements. The warming-up movement consists of nine movements, the core movement consists of five. Each movement consist of A and $\mathrm{B}$, and the cooling down movement consists of six movements. Its seen from the movements and music that accompany the physical fitness gymnastics 2012 by using moderate intensity. All the movements contained in physical fitness trainings 2012 involve all the muscles of the body and limbs from top to bottom, so that the main goal of training in these activities will be easily achieved. And all 
Hasanuddin Jumareng, Asmuddin, Aliasis Maruka, Abdul Saman, Badaruddin, Edi Setiawan, Abdurrohman Muzakki (2021)

The Effect Of Physical Fitness Gymnastics Training 2012 On Increasing Of Physical Fitness

\section{OLAHRAGA}

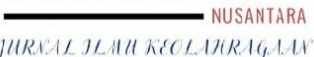

Jendral A. Yani Street Lorong Gotong Royong 9/10 Ulu

Palembang South Sumatera

Accredited

email jurnal: jurnalhon@univpgri-palembang.ac.id

situs web: http://www.univpgri-palembang.ac.id

of that combined into one form of package training. The time duration needed to done one training is 14 minutes and 56 seconds. The method of physical fitness gymnastics 2012 is based on the sequence, namely (1) warm-up training make all students movement, (2) core tarining that are not tiring and enjoyable for students, (3) cool-down training that are understandable and easy to do with a slow time. Realizing the benefits of learning gymnastics can be used as a way to optimize of skills ability to the students. Gymnastics can increasing the abilities as follows: (1) Agility: in gymnastics that children can change the level or direction of turning their bodies, and turning around or walking using the body (2) Balance: some movements in dance require a good degree of symmetry and asymmetry of balance (3) Coordination: walking in different ways and using body parts in different positions around the body and space (Jusuf, Raharja, \& Muhardila, 2019). Children who are directly involved in rhythmic gymnastics will develop flexibility and coordination. In addition, rhythmic gymnastics activities can contribute to enriching the vocabulary of the participants' movements as well as the benefits of physical fitness activities.

Researchers observed that students of Kendari state yunior high school 8, are still less aware the benefits of physical fitness training, as evidenced by the training every Friday, many students unseriously participate in these activities because they are lazy to move, late, don't memorize of movements and so on. Therefore, researchers are interested to determine how the physical fitness training 2012 can be maximally utilized to inceased to students' physical fitness. To find out exactly according to the facts in the field about the physical fitness status of students Kendari state yunior high school 8 , it is necessary to conduct the research and specific studies. Therefore, the aim of this study is to examine the effects of using physical fitness exercises in 2012 to improve aspects of students' physical fitness. 


\section{HALAMAN Jendral A. Yani Street Lorong Gotong Royong 9/10 Ulu OLAHRAGA Palembang South Sumatera \\ Accredited

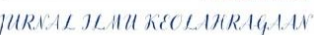

\section{METHOD}

The method used is a quantitative of field experimental research and development (Juniarta \& Siswantoyo, 2014), stated that research and development is a research method to produce educational products, both products in the form of material objects and videos. Experimental research is research that aims to determine the cause and effect that occurs in research subjects after being given an action or treatment. In this research using a quasi-experimental method, the design of this research is One Group Pretest-Posttest Design (Soraya et al., 2019), namely a research design that contains a pretest before being treated and a posttest after being treated. In this case, the treatment is given for 6 weeks with 3 times a week meetings to incease of physical fitness on physical fitness training in 2012, of girls at the students of Kendari state yunior high school 8. Thus it can be known to be more accurate because it can compare to the held before being treated.

Population is a generalization area consist of: objects/subjects that have certain qualities and characteristics that are applied by researchers to research and taken conclusions in (Soraya et al., 2019). The population in this research were all the students of class VII Kendari state yunior high school 8, totaling 98 students, with details of class VII-a totaling 32 people, class VII-b totaling 33 and class VII-c totaling 32 people. Sampling by using random sampling, the sample of this research were 10 girls at the students of Kendari state yunior high school 8. The sampling instrument used by control variables, namely gender and age, after which each class was taken randomly to represent each class. Representatives of class VII-a 3 people, class VII-b 4 people and class VII-c 3 people, so that the total sample amounted to 10 students from the results of lottery. This research used the Indonesian Physical Fitness Test for the 13-15 year old category. The instrument used in this research was the 800 meter run, aimed to measure the heart endurance, blood circulation, and lungs. Overall to measure the level of students 
Hasanuddin Jumareng, Asmuddin, Aliasis Maruka, Abdul Saman, Badaruddin, Edi Setiawan, Abdurrohman Muzakki (2021)

The Effect Of Physical Fitness Gymnastics Training 2012 On Increasing Of Physical Fitness

\section{HALAMAN Jendral A. Yani Street Lorong Gotong Royong 9/10 Ulu OLAHRAGA Palembang South Sumatera \\ Accredited \\ JURAALHAIKKOLIRRGAA Situs web: http://www.univpgri-palembang.ac.id SINTA 3}

physical fitness. Data analysis using IBM SPSS 25.0 for find normality, homognity and paired sample t-test.

\section{RESULTS AND DISCUSSION}

Based on the results of the research, there is a distribution of the presentation the 800 meter pre-test results from 10 students as many as 8 people (80\%) with a time record of 4'59 "00 - 6'40" 00. As many as 2 people (20\%) with a record time of 6'41 "00 and so on.

Table 1. Frequency Distribution 800 Meter Running Test of Pre-test Results

\begin{tabular}{ccc}
\hline The Result of 800 Meter running & $\begin{array}{c}\text { Frequency } \\
\text { Absolut (fo) }\end{array}$ & $\begin{array}{c}\text { Frequency } \\
\text { Relative (\%) }\end{array}$ \\
\hline 4'59"00 - 6'40"00 & 8 & $80 \%$ \\
6'41"00 - dst & 2 & $20 \%$ \\
Total & 10 & $100 \%$ \\
\hline
\end{tabular}

The data of post test results from 10 students were 2 people (20\%) with a record time of 3'07 "00 - 3'55" 00. A total of 5 people (50\%) with a record time of 3'56 "00 - 4'58" 00. A total of 3 people (30\%) with a record time of 4'59 "00 6'40" 00 .

Table 2. Frequency Distribution 800 Meter Running Test of Post-Test Results

\begin{tabular}{ccc}
\hline The Result of 800 Meter running & $\begin{array}{c}\text { Frequency } \\
\text { Absolut (fo) }\end{array}$ & $\begin{array}{c}\text { Frequency } \\
\text { Relative (\%) }\end{array}$ \\
\hline 3'07'00 - 3'55'00 & 2 & $20 \%$ \\
3'56'00-4'58'00 & 5 & $50 \%$ \\
4'59'00-6'40"00 & 3 & $30 \%$ \\
Total & 10 & $100 \%$ \\
\hline
\end{tabular}

The results of the distribution normality test for the physical fitness variables to the pre-test and post-test given the results that physical fitness is normally distributed with the Sig. pre-test $=0.060$ and the Sig. post-test $=0.067$. Because of the Sig. for both groups $>0.05$.

Table 3. Data Normality Test

\begin{tabular}{cc}
\hline Activities & P-Value \\
\hline Pre-Test & 0.482 \\
Post-Test & 0.254 \\
\hline
\end{tabular}


Tabel 4. Homogeneity Test

\begin{tabular}{cccc}
\hline Levene Statistic & df1 & df2 & $P$-Value \\
\hline 1.702 & 1 & 18 & 0.209 \\
\hline
\end{tabular}

Based on the output table of homogeneity variances test above, it is known that the significance value (Sig.) of pre-test and post-test variables for students is 0.209. Because of the Sig. $0.209>0.05$, so as the basis for decision making on the homogeneity test above, it can be concluded that the variance of pre and post result data is the same / homogeneous.

Tabel 5. Paired sample t-test

\begin{tabular}{ccc}
\hline Activities & $\mathrm{t}$ & P-Value \\
\hline Pre-Test & 5.721 & 0.002 \\
Post-Test & 6.474 & 0.006 \\
\hline
\end{tabular}

The results of t-test on physical fitness showed that physical fitness had a significant effect with $\mathrm{t}^{\text {count }}>\mathrm{t}^{\text {table }}$, and $P$-Value $<0.05$.

The research that has been done shows that the physical fitness at the students of Kendari yunior high school 8 is 10 people at the pre-test measurement in the lowest physical fitness with a record time of 6'58 "06 with a value of 1 and the highest physical fitness with a record time of 5'00" 01 with value 2 . While the post-test measurement of the lowest physical fitness with a record time of 5'29 "02 with a value of 2 and the highest physical fitness with a record time of 3'50" 01 with a value of 4 . Based on the results of research that has been carried out the value of physical fitness before and after treatment, there is an increased. Providing treatment for six weeks with a frequency of training to 3 times in week. The training activity provided is the physical fitness gymnastics training 2012 which aims to inceased of physical fitness. So it can be concluded that the rhythm of the trainings heavier or faster, so the physical fitness gymnastics training 2012 is easier to done. This form of test has several advantages including the data obtained is valid and can be carried out properly. 
Hasanuddin Jumareng, Asmuddin, Aliasis Maruka, Abdul Saman, Badaruddin, Edi Setiawan, Abdurrohman Muzakki (2021)

The Effect Of Physical Fitness Gymnastics Training 2012 On Increasing Of Physical Fitness

\section{OLAHRAGA}

JURALL JUII KCOL MURANTARA

Jendral A. Yani Street Lorong Gotong Royong 9/10 Ulu

Palembang South Sumatera

Accredited

email jurnal: jurnalhon@univpgri-palembang.ac.id

situs web: http://www.univpgri-palembang.ac.ic

Based on the results of hypothesis testing that has been done previously, it is

stated that $\mathrm{H}_{0}$ is rejected and $\mathrm{H}_{1}$ is accepted, so that it can be shows that there is an effect of physical fitness gymnastics training 2012 on inceasing the physical fitness at the students of Kendari yunior high school 8. It can be concluded that become more and more often to done of training, so better to increased of students physical fitness either. The results of this study support previous studies which confirm that a program of exercise or physical activity, namely regular 2012 exercise can increase cardiorespiratory breathing, resistance, flexibility, and neuromotor outside activities of daily life and maintain physical fitness and health (Mason, Horvat, \& Nocera, 2016; Sterkowicz-Przybycień et al., 2019). In addition, according to Wirnantika, Pratama, \& Hanief, (2017) that physical fitness has an important role for children to make them physically, mentally and emotionally ready, psychological (Safaringga \& Herpandika, 2018) and physical maturity, and lead children to the enthusiasm for learning and training so that they will carry out learning achievements expected.

\section{CONCLUSION}

Based on the description at the results of the discussion in this research as well as from the data processing that has been carried out, it can be concluded that there is an effect of physical fitness gymnastics training 2012 on inceasing the physical fitness at the students of Kendari yunior high school 8.

\section{ACKNOWLEDGMENTS}

My gratitude goes to the University of Halu Oleo who have provided support in the implementation of this research.

\section{REFERENCES}

Abdurrahim, F., \& Hariadi, I. (2018). Tingkat Kebugaran Jasmani Siswa SDNTulungrejo 03 Daerah Dataran Tinggi Kecamatan Bumiaji Kota Batu Tahun Pelajaran 2018/2019. Ilmu Keolahragaan, ISSN 2597-(1), 68-73.

Aminah, H., Shadiqin, A. R., \& Kahri, M. (2020). Effect of Physical Fitness Exercises in 2012 and New Indonesian Gymnastics Exercise ( SRIBU ) 
Hasanuddin Jumareng, Asmuddin, Aliasis Maruka, Abdul Saman, Badaruddin, Edi Setiawan, Abdurrohman Muzakki (2021)

The Effect Of Physical Fitness Gymnastics Training 2012 On Increasing Of Physical Fitness

HALAMAN

$\underline{\text { OLAHRAGA }}$

JURALL JHUKCOLDRAQLA

Accredited

email jurnal: jurnalhon@univpgri-palembang.ac.id situs web: http://www.univpgri-palembang.ac.id

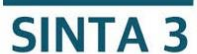

Exercises on Physical Fitness Level of Female Students. Advances in Social Science, Education and Humanities Research, 407(Sbicsse 2019), 73-75.

Anggitasari, E. D., Dieny, F. F., \& Candra, A. (2019). Hubungan somatotype dengan kesegaran jasmani atlet sepak bola. Jurnal Keolahragaan, 7(1), 1122. https://doi.org/10.21831/jk.v7i1.21188

Bayu, W.I., Destriana, Victorian, A.R., Yusfi, H \& Solahuddin, S. (2021). Fitness level effect on the grade-point average of Physical education major students. Halaman Olahraga Nusantara (Jurnal Ilmu Keolahragaan), 4(2)180-192. http://dx.doi.org/10.31851/hon.v4i2.5239

Chen, W., Hammond-Bennett, A., Hypnar, A., \& Mason, S. (2018). Healthrelated physical fitness and physical activity in elementary school students. BMC Public Health, 18(1), 1-13. https://doi.org/10.1186/s12889-018-5107-4

Juniarta, T., \& Siswantoyo, S. (2014). Pengembangan Model Permainan Rintangan (Handicap Games) Untuk Latihan Kebugaran Jasmani Anak Usia 10-12 Tahun. Jurnal Keolahragaan, 2(1), 88-105. https://doi.org/10.21831/jk.v2i1.2606

Jusuf, J. B. K., Raharja, A. T., \& Muhardila, N. A. (2019). The Development Of Ritmic Gymnastic Model To Improve Basic Movement And Interest In Rytmic Gymnastic. Acitya Journal of Teaching \& Education, 1(1), 72-85. Retrieved from http://journals.umkt.ac.id/index.php/acitya

Mason, R. C., Horvat, M., \& Nocera, J. (2016). The Effects of Exercise on the Physical Fitness of High and Moderate-Low Functioning Older Adult Women. Journal of Aging Research, 2016, 1-7. https://doi.org/http://dx.doi.org/10.1155/2016/8309284

Pasaribu, A., \& Mashuri, H. (2019). The role of rhythmic gymnastics for physical fitness for elementary school students. Jurnal Penelitian Pembelajaran, 5. https://doi.org/https://doi.org/10.29407/js_unpgri.v5i1.12551

Patah, I. A., Jumareng, H., Setiawan, E., Aryani, M., \& Gani, R. A. (2021). Sport (2021),

108-122. https://doi.org/https://doi.org/10.25299/sportarea.2021.vol6(1).6172 How

Safaringga, E., \& Herpandika, R. P. (2018). Hubungan Antara Kebugaran Jasmani Dengan Kualitas Tidur. Jurnal SPORTIF : Jurnal Penelitian Pembelajaran, 4(2), 236-247. https://doi.org/DOI: https://doi.org/10.29407/js_unpgri.v4i2.12467

Setiawan, E., Iwandana, D. T., Festiawan, R., \& Bapista, C. (2020). Improving handball athletes' physical fitness components through Tabata training during the outbreak of COVID-19. Jurnal SPORTIF, 6(2), 375-389. https://doi.org/10.29407/js_unpgri.v6i2.14347 
Hasanuddin Jumareng, Asmuddin, Aliasis Maruka, Abdul Saman, Badaruddin, Edi

Setiawan, Edi, Budiarto, \& Afriyuandi, A. R. (2020). Korelasi Antara Physical Activity dan Physical Fitness Pada Atlet Bolabasket Level Pemula. Jurnal Pendidikan Olahraga Dan Kesehatan, 9(2), 197-208. https://doi.org/10.31571/jpo.v9i2.2005

Soraya, I., Sugihartono, T., \& Defliyanto, D. (2019). Pengaruh Latihan Skj 2018 Terhadap Peningkatan Kebugaran Jasmani Mahasiswa Putri Penjas Unib. Kinestetik, 3(2), 249-255. https://doi.org/10.33369/jk.v3i2.8998

Sterkowicz-Przybycień, K., Sterkowicz, S., Biskup, L., Zarów, R., Kryst, Ł., \& Ozimek, M. (2019). Somatotype, body composition, and physical fitness in artistic gymnasts depending on age and preferred event. PLOS ONE, 14(2), 1-21. https://doi.org/10.1371/journal.pone.0211533

Sukamanti, E. R., Budiarti, R., \& Nurfadhila, R. (2020). Effect Of Physical Conditioning On Student Basic Skills Gymnastics, 39(1), 207-216. https://doi.org/10.21831/cp.v39i1.29641

Sukamti, E. R., Zein, M. I., \& Budiarti, R. (2016). Profil Kebugaran Jasmani Dan Status Kesehatan Instruktur Senam Aerobik Di Yogyakarta. Jurnal Olahraga Prestasi, 12(2), 116313. https://doi.org/10.21831/jorpres.v12i2.11875

Susanto, M.D \& Nuraini, S. (2019). Media For The Implementation Of Games With Swiss Ball Media To Improve Resistance (In Kop Aerob Students, Jakarta Gymnastics, State University). Halaman Olahraga Nusantara (Jurnal Ilmu Keolahragaan), 2(2), 97-197.

Wanto, S. (2018). Motivation Of Fitness Center Members In Following Fitness Exercise At The Sekayu City. Halaman Olahraga Nusantara (Jurnal Ilmu Keolahragaan, 1(1),1-132

Wirnantika, I., Pratama, B. A., \& Hanief, Y. N. (2017). Survey Tingkat Kebugaran Jasmani Siswa Kelas IV SDN Puhrubuh I Dan MI Mambaul Hikam di Kabupaten Kediri Tahun Ajaran 2016/2017. Jurnal Pembelajaran Olahraga, 3(2), 241-250. https://doi.org/https://doi.org/10.29407/js_unpgri.v3i2.11898

Xu, C., Yao, M., Kang, M., \& Duan, G. (2020). Improving Physical Fitness of Children with Intellectual and Developmental Disabilities through an Adapted Rhythmic Gymnastics Program in China. BioMed Research International, 2020, 1-10. https://doi.org/10.1155/2020/2345607 